\title{
PERHIASAN PADA SUKU KOMBAI, BOVEN DIGOEL (Jewelery of Kombai Tribe, Boven Digoel)
}

\author{
Sonya M. Kawer \\ Balai Arkeologi Jayapura \\ balar_jpr@yahoo.co.id
}

\begin{abstract}
Tribal jewelry Kombai also know their traditions and culture. This tradition has been introduced by their ancestors in ancient times. This paper to learn about the form and function of accessories or jewelry Kombai Tribe. The method of data collection is done with literature, field surveys, and analysis using Ethnoarchaeology approach. In the form of jewelry is jewelry Kombai tribal head or crown of the head, nose ornaments, decorations arm, necklaces, body decoration, penis sheath for men, skirts for women tassel, and ornate legs. All these accessories are made or derived from the nature around them stay.
\end{abstract}

Keywords: jewelery, Kombai tribe, function

\begin{abstract}
ABSTRAK
Suku Kombai juga mengenal perhiasan dalam tradisi dan kebudayaan mereka. Tradisi ini sudah diperkenalkan oleh nenek moyang mereka pada zaman dahulu. Tulisan ini untuk mengetahui mengenai bentuk asesoris atau dan fungsi perhiasan Suku Kombai. Metode pengumpulan data dilakukan dengan studi pustaka, survei lapangan, dan analisis menggunakan pendekatan etnoarkeologi. Bentuk perhiasan pada suku Kombai yaitu perhiasan kepala atau mahkota kepala, hiasan hidung, hiasan lengan tangan, kalung, hiasan badan, koteka untuk laki-laki, rok rumbairumbai untuk perempuan, dan hiasan kaki. Semua asesoris ini terbuat atau berasal dari alam sekitar mereka tinggal.
\end{abstract}

Kata kunci: perhiasan, Suku Kombai, fungsi

Tanggal masuk : 17 September 2014

Tanggal diterima : 3 November 2014 


\section{PENDAHULUAN}

Sisa-sisa kehidupan prasejarah menunjukan kemampuan manusia yang terbatas dalam memanfaatkan bahan-bahan yang disediakan oleh alam sekitarnya. Alat-alat keperluan hidup dibuat dari kayu, batu, dan tulang dengan pembuatan yang sederhana, sekedar memenuhi tujuan penggunaannya. Teknologi pada tingkat permulaan mengutamakan segi praktis, sesuai dengan tujuan penggunaannya saja, yang makin lama makin meningkat kearah penyempurnaan bentuk perkakasperkakas keperluan hidup. Pada taraf peningkatan ini, yang bukti-buktinya terutama ditemukan di Eropa, tampak kecenderungan ke arah pengutaraan rasa keindahan dan rasa keterikatan pada peristiwa-peristiwa alam. Kondisi ini menjadi landasan dari beberapa segi kehidupan rohani manusia, yaitu seni dan kepercayaan. (Soejono dan Leirissa, 2007:39).

Keadaan alam yang melatar belakangi kehidupan manusia pada masa prasejarah ditandai oleh beberapa peristiwa yang amat besar pengaruhnya terhadapat kehidupan manusia. Alam menyediakan segala kebutuhan untuk hidup. Untuk menjaga kelangsungan hidup. Manusia mempunyai kelebihan dari segala jenis hewan lainnya dalam hal memiliki akal yang lebih berkembang. Perkembangan akal-budi manusia yang tercermin dari hasil budaya yang diciptakan itu amat dipengaruhi oleh lingkungan alam sekitarnya (Notosusanto, 1993:2).

Tradisi prasejarah di Indonesia masih berlangsung hingga saat ini. Sumber-sumber etnografi melukiskan kehidupan beberapa suku yang masih terdapatunsur-unsurprasejarah berupa aspek kehidupan sosial ekonomi dan kepercayaan (Soejono dan Leirissa, 2007:433). Setelah cara hidup berburu dan mengumpulkan makanan dilampaui, manusia menginjak suatu masa kehidupan yang disebut masa bercocok tanam. Masa ini amat penting dalam sejarah perkembangan dan peradaban masyarakat karena pada masa ini beberapa penemuan baru berupa penguasaan sumber-sumber alam bertambah cepat(Soejono dan Leirissa, 2007:203).

Salah satu kebutuhan manusia selain memanfaatkan alam sebagai kehidupan sehari-hari, alam juga dimanfaat sebagai suatu hal yang dapat dilihat menarik dan memiliki nilai tersendiri. Contoh pada kulit kayu melinjo yang dapat dibuat noken bahkan asesoris pada tubuh manusia. Manik-manik hutan dan beberapa jenis-jenis tumbuhan yang dapat di fungsikan sebagai hiasan pada tubuh manusia.

Bersumber dari pemikiran manusia yang cerdas dan dibantu dengan tangannya yang dapat memegang sesuatu dengan erat, manusia dapat membuat dan mempergunakan alat. Dengan alatalat ciptaannya itulah manusia dapat membuat dan mempergunakan alat serta dapat lebih mampu mencukupi kebutuhannya. Misalnya pada pakaian sampai pada asesoris yang dimilikinya yang terbuat dari alam.

Istilah perhiasan dalam kamus bahasa Indonesia adalah sesuatu yang dipakai untuk menghiasi diri. Oleh sebab itu suku-suku di Papua lebih khusus pada suku Kombai juga memiliki perhiasan yang dipakai menghias diri dan memiliki nilai tersendiri dalam adat-istiadat dan kebudayaannya. Di Papua masih terlihat tanda-tanda bertahannya tradisi prasejarah sampai jauh memasuki masa sejarah, bahkan hingga masa kini. Sumber-sumber etnografi melukiskan kehidupan beberapa suku menunjukan masih terdapatnya unsur-unsur prasejarah yang mengendap di dalam kehidupan masyarakat. Beberapa unsur 
tersebut mengendap dalam beberapa aspek kehidupan sosial ekonomi, kepercayaan, dan seni. Ciri-ciri fisiografi daerah Papua memiliki sistem mata pencaharian hidup dan pola beradapetasi penduduk terhadap lingkungan alamnya berbeda-beda antara satu atau beberapa golongan etnik dengan golongan etnik lainnya berdasarkan berbedaan lingkungan ekologi yang menjadi tempat tinggal mereka. Selain itu perkembangan struktur sosial masyarakat juga turut ditentukan oleh proses-proses adaptasi oleh lingkungan alamnya. Atau dengan perkataan lain faktor lingkungan alam turut menentukan sistem-sistem teknologi dan organisasi sosial dari masyarakat yang digunakan untuk beradaptasi bagi lingkungan alamnya (Mansoben, 1995:34)

Fokus tulisan ini adalah tradisi prasejarah pada suku Kombai di Distrik Bomakia, Boven Digoel. Suku Kombai memiliki warisan asesoris atau perhiasan yang digunakan dalam adat istiadat. Berdasarkan pada latar belakang tersebut di atas, terdapat beberapa permasalahan yang dapat diuraikan mengenai bentuk dan fungsi asesoris pada suku Kombai. Metode yang digunakan dalam penelitian ini dengan pengumpulan data dengan cara: studi kepustakaan, untuk menjaring informasi tertulis dari buku-buku, artikel, maupun laporan yang berkaitan dengan penelitian sebagai bahan referensi. Survei, dengan cara melakukan pengamatan langsung di lapangan dengan format pengambilan data, baik yang bersifat verbal (pencatatan dan pengukuran), maupun piktorial (pemotretan dan penggambaran). Wawancara juga dilakukan secara selektif pada tokoh adat untuk menampung informasi tentang bentuk perhiasan yang dimiliki mengetahui fungsi perhiasan yang masih disimpan atau dimiliki oleh penduduk setempat.

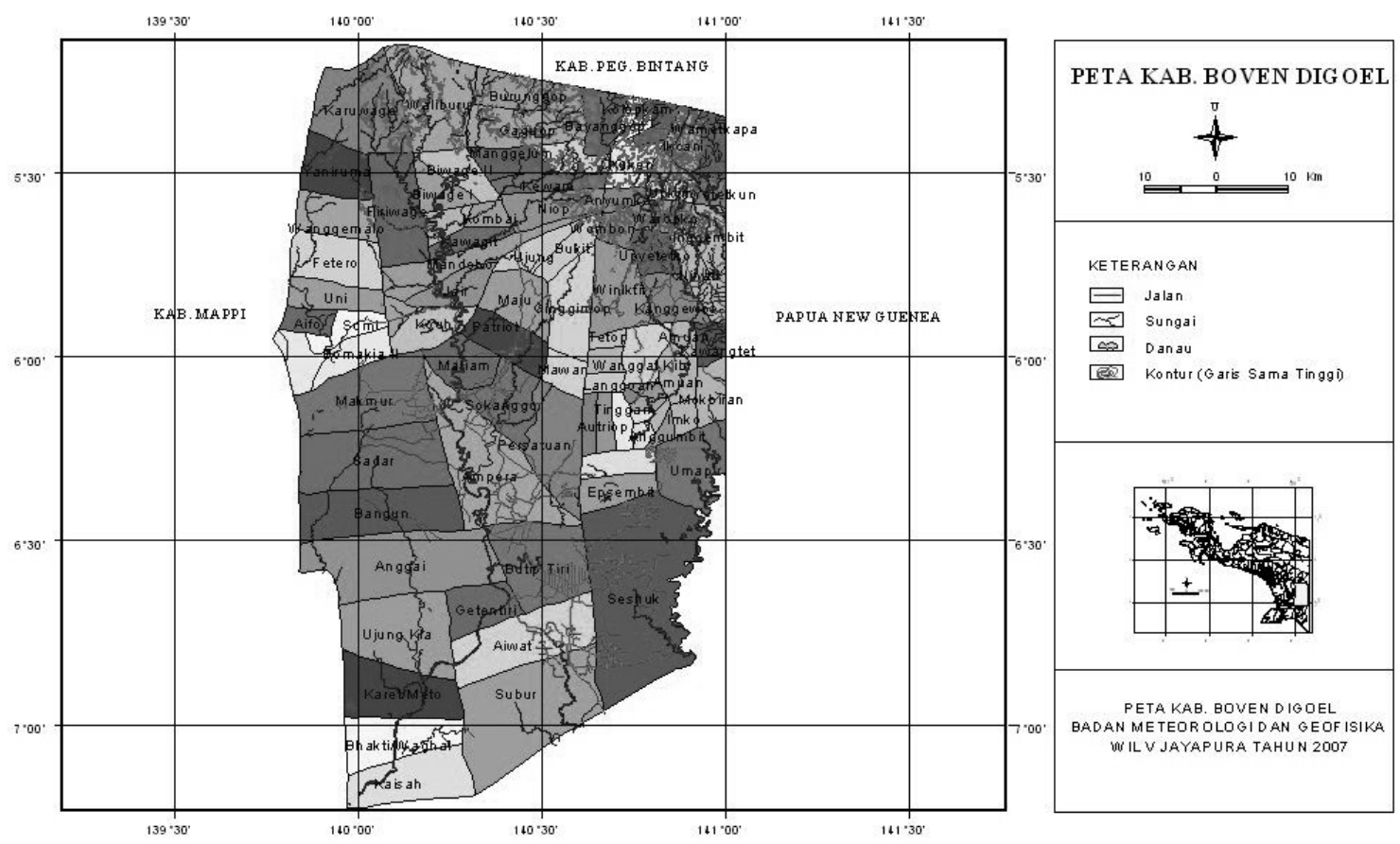




\section{Bentuk Perhiasan Suku Kombai}

Kebudayaan Suku Kombai telah ada sejak nenek moyang mereka hingga sekarang, yang dijadikan sebagai sebuah identitas diri. Menurut Koentjaraningrat telah mengartikan kebudayaan sebagai seluruh gagasan dan karya manusia, yang harus dibiasakannya dengan belajar beserta keseluruhan dari hasil budi dan karyanya itu. Wujud kebudayaan dalam Koentjaraningrat terdapat 3 wujud yang serupa yaitu: sebagai suatu kompleks dari ide, gagasan, nilai-nilai, normanorma, peraturan dan sebagainya, wujud kebudayaan sebagai suatu kompleks aktivitas kelakuan berpola dari manusia dalam masyarakat, wujud kebudayaan sebagai benda-benda hasil karya manusia.

Wujud tanpa keyataan tidak memiliki arti namun berdasarkan pengalaman hidup konkrit akan memiliki arti mendalam sebagaimana pada suku kombai yang memiliki sebuah identitas budaya yang masih dijaga dan dimanfaatkan hingga sekarang. Oleh sebab itu suku Kombai dikenal sebagai salah satu suku yang masih memiliki asesoris atau perhiasan yang dipakai dalam tradisi budaya mereka mulai dari, berperang, perkawinan, dan alat tukar. Semua perhiasan ini terbuat atau memanfaatkan alam sekitar.

Dari hasil penelitian ini ditemukan beberapa perhiasan yang dipakai oleh laki-laki dan perempuan. Berikut ini merupakan tabel dari bentuk perhiasan yang dipakai oleh suku Kombai.

Tabel 1. Bentuk hiasan pada laki-laki

\begin{tabular}{|c|l|l|l|}
\hline No & \multicolumn{1}{|c|}{ Bentuk hiasan } & \multicolumn{1}{|c|}{ Bahan } & \multicolumn{1}{|c|}{ Fungsi } \\
\hline 1 & $\begin{array}{l}\text { Makota kepala jenis pertama } \\
\text { (firafhuo })\end{array}$ & $\begin{array}{l}\text { Kulit kus-kus pohon + kulit kerang } \\
\text { cowries, (rakhi) + manik-manik rumbut }\end{array}$ & diikat di atas alis / testa \\
\hline 2 & $\begin{array}{l}\text { Makota kepala jenis kedua } \\
\text { (Mimina) }\end{array}$ & $\begin{array}{l}\text { Tali rotan + pucuk daun sagu + manik- } \\
\text { manik rumput (wame) }\end{array}$ & topi \\
\hline 3 & Hiasan hidung (yani) & Batu + kulit kerang & $\begin{array}{l}\text { Batu yang diasah ukuran hidung } \\
\text { dan kerang yang dipotong } \\
\text { ukuran sedang dipasang di } \\
\text { tengah-tengah antara lubang } \\
\text { hidung }\end{array}$ \\
\hline 4 & Hiasan lengan tangan (Rafe) & Kulit pohon nibung & $\begin{array}{l}\text { Kulit nibung dianyam bulat } \\
\text { ukuran tangan }\end{array}$ \\
\hline 5 & Kalung (Wuhu) & $\begin{array}{l}\text { Gigi babi (aimba) + kulit pohon melinjo } \\
\text { (li) }\end{array}$ & $\begin{array}{l}\text { Gigi babi diikat pada anyaman } \\
\text { tali pintalan melinjo dan } \\
\text { digunakan pada bagian leher }\end{array}$ \\
\hline 6 & Hiasan badan (Ranggaleho) & $\begin{array}{l}\text { Gigi anjing (manggi) + kulit pohon } \\
\text { melinjo (li) }\end{array}$ & $\begin{array}{l}\text { Gigi anjing diikat pada pintalan } \\
\text { kulit melinjo. Disilang pada } \\
\text { bagian badan }\end{array}$ \\
\hline 7 & Koteka (Umo) & $\begin{array}{l}\text { Moncong burung taong-taong (Riambo) } \\
\text { dan kulit labu }\end{array}$ & $\begin{array}{l}\text { Dipakai pada bagian alat } \\
\text { kelamin lelaki }\end{array}$ \\
\hline 8 & Gelang kaki (dofi) & Kulit pohon nibung & $\begin{array}{l}\text { Kulit nibung dianyam bulat } \\
\text { ukuran pergelangan kaki }\end{array}$ \\
\hline
\end{tabular}

Sumber: Balai Arkeologi Jayapura, 2014 
Tabel 2. Bentuk hiasan pada perempuan

\begin{tabular}{|c|c|c|c|}
\hline No & Bentuk hiasan & Bahan & Fungsi \\
\hline 1 & $\begin{array}{l}\text { Makota kepala } 1 \\
\text { (amyamoho) }\end{array}$ & Manik-manik rumput & Diikat di atas alis/ testa \\
\hline 2 & $\begin{array}{l}\text { Makota kepala jenis kedua } \\
\text { (amyamoho) }\end{array}$ & Pucuk pohon sagu & Dianyam dan ikat di atas kepala \\
\hline 3 & Hiasan hidung (yani) & Batu & $\begin{array}{l}\text { Batu yang diasah ukuran hidung } \\
\text { dipasang di tengah-tengah antara } \\
\text { lubang hidung }\end{array}$ \\
\hline 4 & $\begin{array}{l}\text { Hiasan lengan tangan } \\
\text { (Rafe) }\end{array}$ & Kulit pohon nibung hutan & $\begin{array}{l}\text { Kulit nibung dianyam bulat ukuran } \\
\text { tangangan }\end{array}$ \\
\hline 5 & Kalung (aerali) & Gigi babi + kulit pohon melinjo & $\begin{array}{l}\text { Gigi babi diikat pada anyaman tali } \\
\text { pintalan melinjo dan digunakan pada } \\
\text { bagian leher }\end{array}$ \\
\hline 6 & Hiasan badan (Ranggaleho) & Gigi anjing + kulit pohon melinjo & $\begin{array}{l}\text { Gigi anjing diikat pada pintalan kulit } \\
\text { melinjo, disilang pada bagian badan }\end{array}$ \\
\hline 7 & $\begin{array}{l}\text { Rumbai-rumbai atau rok } \\
\text { (Fiyo) }\end{array}$ & Pucuk daun sagu & $\begin{array}{l}\text { Dipintal dan dibuat berbentuk rok } \\
\text { rumbai-rumbai }\end{array}$ \\
\hline 8 & $\begin{array}{l}\text { Bra atau pakian dalam } \\
\text { (Ranggali) }\end{array}$ & Kulit pohon melinjo & $\begin{array}{l}\text { Kulit pohon melinjo di pintal dan di } \\
\text { anyam berbentuk pakian dalam }\end{array}$ \\
\hline
\end{tabular}

Sumber: Balai Arkeologi Jayapura, 2014
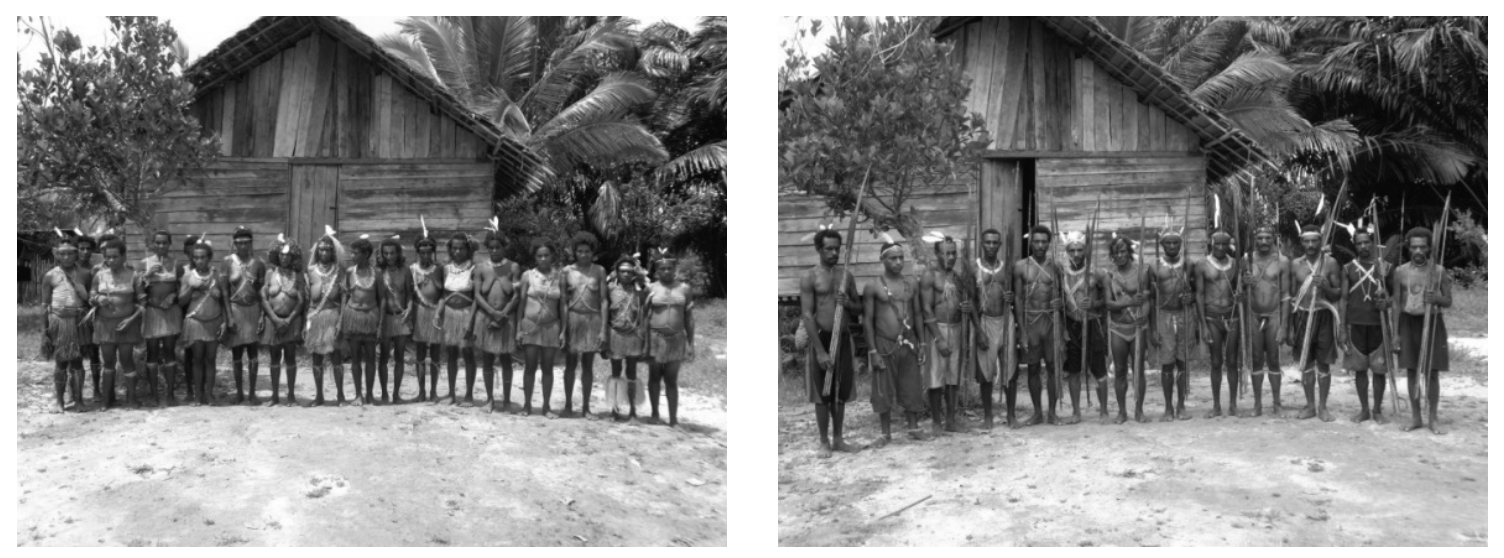

Gambar 1. Suku Kombai (dokumentasi Balai Arkeologi Jayapura)

\section{Bahan dari fauna}

Perhiasan yang berasal dari fauna yaitu gigi seri babi yang dilubangi bagian pangkalnya untuk dijadikan perhiasan kalung, taring babi dan kuku burung elang yang digunakan sebagai hiasan hidung, gigi anjing yang bagian pengkalnya dilubangi untuk dijadikan perhiasan. Bagian lain dari binatang yang juga digunakan adalah paruh atas burung taon-taon yang dijadikan sebagai alat penutup kelamin laki-laki. Awetan burung cendrawasih maupun kulit binatang kuskus dijadikan hiasan kepala.

\section{Bahan kulit kerang}

Terdapat beberapa benda budaya dari bahan kulit kerang yang dijadikan sebagai mata uang, mas kawin, perhiasan, alat serut dan penutup alat kelamin laki-laki. Ada lima jenis kerang yang digunakan yaitu untuk mata uang, mas kawin dan perhiasan dari cangkang kerang kelas cypraea erosaria moneta, kelas pectinidae serratovola tricarinatus, kelas volutidae melo-melo, dan kelas fasciolariidae saginafusus pricei, dan alat serut dari cangkang moluska air tawar kelas mytilidae modiolus proclivis iredale 

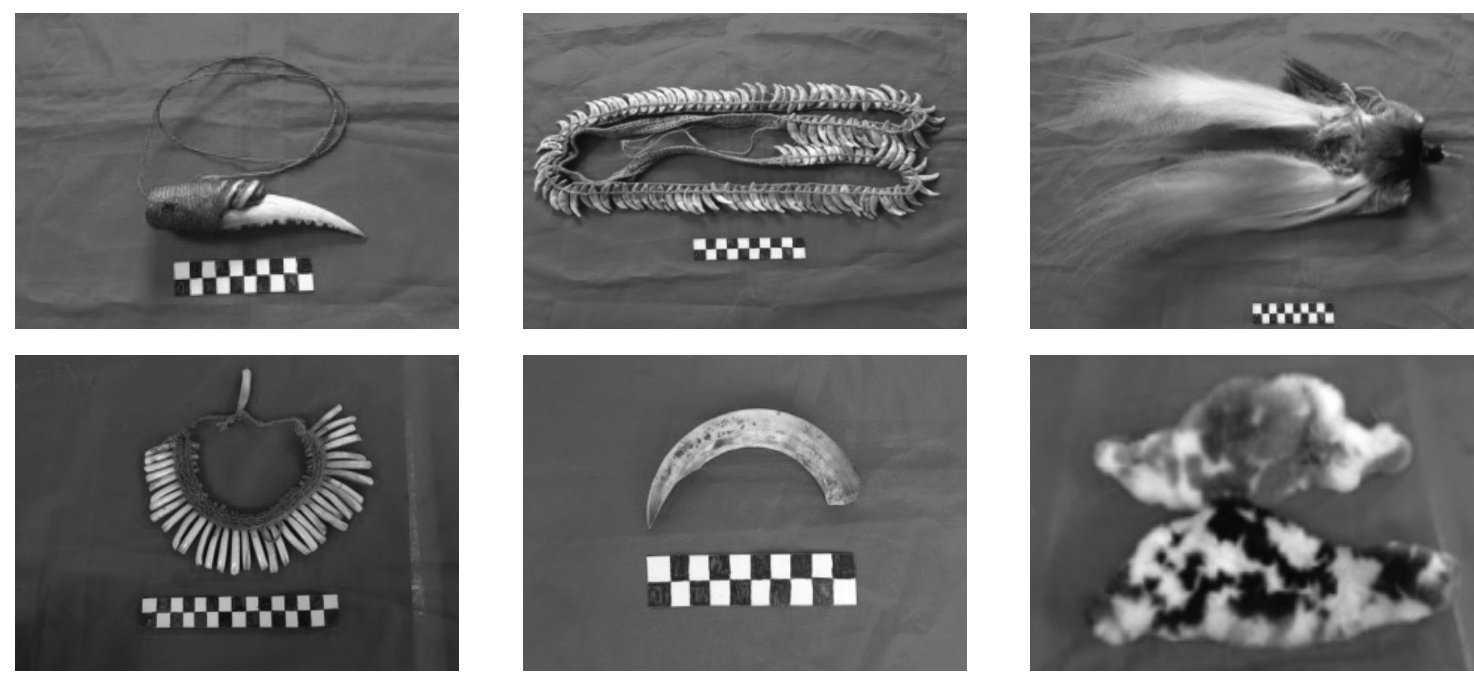

Gambar 2. Asesoris dari bahan binatang (dokumentasi Balai Arkeologi Jayapura)

serta penutup kelamin laki-laki dari cangkang moluska kelas fasciolariidae saginafusus pricei. Diketahui ada lima jenis cangkang moluska yang digunakan tersebut yang jenis merupakan kerang laut
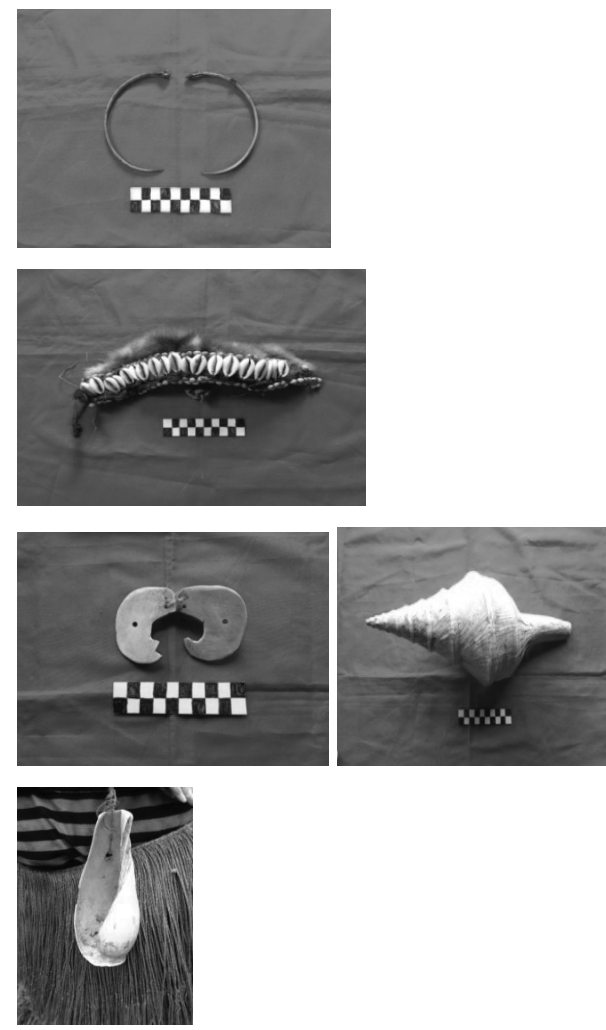

Gambar 3. Asesoris dari bahan kerang (dokumentasi Balai Arkeologi Jayapura)

\section{Bahan dari tumbuhan}

Bahan yang diambil dari daun pucuk pohon sagu yang dikeringkan kemudian dipintal untuk membuat rok rumbai-rumbai, hiasan kepala bagi perempuan dan laki-laki, daun sagu dianyam untuk pembuatan gelang, anyaman dari pintalan serat kulit pohon kayu melinjo untuk pembuatan selempang, bra, tali pengikat mata uang, pembuatan noken. Biji buah rumput manik-manik sebagai perhiasan badan. Kulit kayu ifi untuk menempel kulit kerang sebagai hiasan kepala, anayaman pelepah nibun untuk dijadikan gelang tangan dan tali dari rotan serta labu holim untuk pembuatan koteka. 

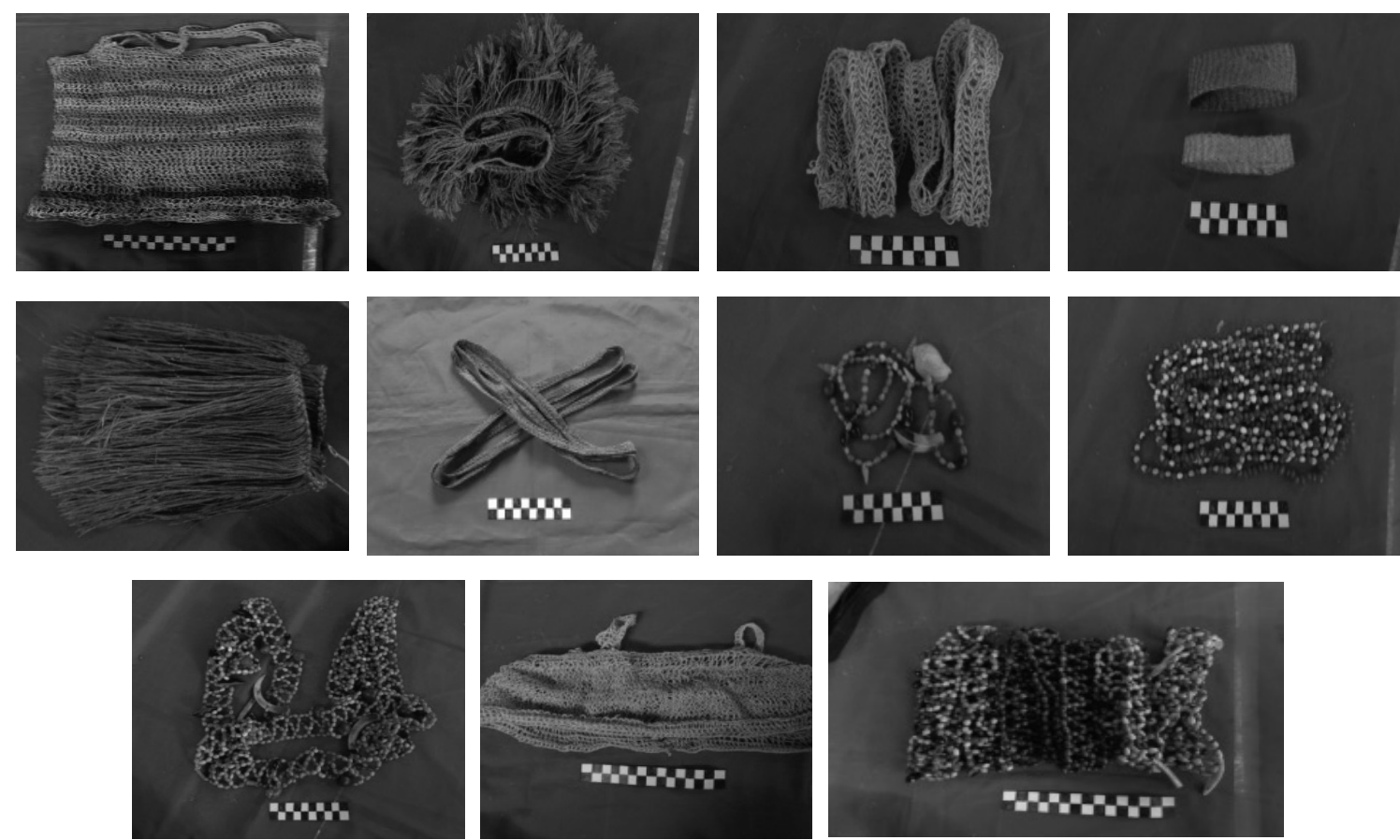

Gambar 4. Asesoris dari bahan tumbuhan (dokumentasi Balai Arkeologi Jayapura)

Perhiasan yang dipakai pada lakilaki dan perempuan suku Kombai mulai dari kepala hingga kaki melambangkan ciri khas masyarakat Kombai sebagai suku yang hidup memanfaatkan alam sekitar sebagai salah satu pendukung budayanya. Karena bahan-bahan pembuatan asesoris mudah diperoleh di sekitar lingkungan mereka tinggal. Mulai dari mendapatkan pohon sagu, karena di daerah Kombai merupakan daerah rawa sehingga pohon sagu yang ditanam dapat tumbuh subur dengan baik, sehingga ujung pucuk pohon sagu dapat difungsikan sebagai asesoris yang dapat digunakan. Kulit pohon melinjo, merupakan salah satu tumbuhan yang ditanam dan juga tumbuh liar dalam hutan, pohon melinjo ini memiliki kulit pohon yang kuat sehingga seratnya dapat dipintal dan diproses menjadi alat kantong, pakaian dan sebuah pintalan ikatan yang dipakai pada benda lain.

Pohon nibung merupakan salah satu pohon yang juga hidup menyebar dalam daerah ini, batang pohon ini hingga kulit pohon berfungsi sebagai hiasan lengan tangan dan kaki yang dipintal. Tali rotan merupakan salah satu tumbuhan yang hidup liar di dalam hutan bersama-sama tumbuhan lainnya, fungsi dari tali rotan ini adalah sebagai alat pengikat atau penyambung suatu benda yang akan digunakan seperti membuat anyaman perhiasan kepala laki-laki.

Manik-manik rumput merupakan jenis tubuhan yang ditanam oleh masyarakat suku Kombai. Manikmanik ini berfungsi sebagai hiasan kalung maupun hiasan kepala yang lebih mempercantik bentuknya. Mulut burung taong-taong dapat diperoleh dengan cara berburu, burung ini hidup disekitar daerah ini, karena bentuk dari mulut burung ini dapat berfungsi sebagai alat penutup kelamin laki-laki.

Labu (lagenaria siceraria) jenis labu ini adalah labu yang berwarna putih dan panjang. Labu ini ditanam dan diproses sehingga berbentuk yang dinamakan koteka yang digunakan oleh kaum laki-laki. Gigi anjing merupakan salah satu hiasan yang dipakain pada bandan untuk mendapatkan gigi anjing 
suku kombai memiliki hewan peliharaan anjing yang selain hewan pemburu juga giginya dapat difungsi sebagai hiasan asesoris yang digunakan dalam budaya mereka.

Gigi babi adalah salah satu perhiasan yang digunakan pada leher, untuk mendapatkan gigi babi suku Kombai sering berburu karena wilayah ini memiliki hutan yang luas sehingga tidak menutupi kemungkinan untuk banyak terdapat hewan ini. Kulit kus-kus, untuk memperoleh kulit kuskus mereka dapat berburu sama hal pada binatang babi yang dilakukan dengan berburu dan kulit dari kus-kus dikeringkan dan digunakan pada bagian kepala dari laki-laki. dan batu yang diasah dan digunakan pada hiasan hidung semua itu mudah diperoleh di sekitar alam mereka tinggal.

Sedangkan kulit kerang couries atau disebut rakhi adalah peninggalan nenek moyang mereka yang diperoleh dari hasil barter atau tukar menukar pada zaman dahulu dengan orang dari daerah luar atau pantai. Karena kerang-kerang ini tidak terdapat di daerah pegunungan atau daerah suku Kombai sendiri. Untuk itu nilai kerang pada suku Kombai memiliki arti dan nilai tersendiri.

Berdasarkan uraian di atas, maka jelaslah bahwa cara hidup berburu dan mengumpulkan makanan berangsurangsur ditinggalkan. Masyarakat mulai menunjukan tanda-tanda menetap di suatu tempat serta mengembangkan penghidupan baru berupa kegiatan bercocok tanam sederhana dan memelihara hewan.

Asesoris tradisional ini dipakai dalam kehidupan sehari-hari mulai dari aktifitas berburu, meramu, mencari ikan, dan religi. Namun pada zaman sekarang mereka hanya gunakan untuk upacara-upacara adat, penyambutan, dan festival budaya. Perhiasan-perhiasan ini masih diwariskan hingga sekarang. Oleh sebab itu budaya Kombai harus tetap dijaga dan kembangkan sebagai salah satu aset warisan budaya bagi anak cucu, generasi selanjutnya.

\section{PENUTUP}

Keadaan alam yang menjadi latar belakang kehidupan manusia pada masa prasejarah ditandai oleh beberapa peristiwa yang amat besar pengaruhnya terhadapat kehidupan manusia. Alam menyediakan segala kebutuhan untuk hidup. Untuk menjaga kelangsungan hidup. Manusia mempunyai kelebihan dari segala jenis hewan lainnya dalam hal memiliki akal yang lebih berkembang. Perkembangan akal-budi manusia yang tercermin dari hasil budaya yang diciptakan itu amat dipengaruhi oleh lingkungan alam sekitarnya.

Berdasarkan pembahasan di atas bahwa suku Kombai yang berada di Distrik Bomakia memiliki budaya yang menarik mulai dari tradisi hidup hingga seni. Dalam kehidupan suku Kombai juga memiliki asesoris atau perhiasan yang digunakan setiap hari atau pada acara-acara adat. Adapun perhiasanperhiasan tersebut adalah makota kepala, hiasan hidung, hiasan lengan tangan, kalung, hiasan badan, koteka (untuk laki-laki), rok rumbai-rumbai (untuk perempuan) dan hiasan kaki. Perhiasan ini semua terbuat dari bahan alam. Mereka bukan saja memanfaat hasil alam sebagai bahan makanan namun hasil alam juga dimanfaatkan sebagai bahan asesoris yang memperindah diri mereka sebagai jati diri suku Kombai. Suku Kombai dikenal sebagai salah satu suku yang masih memiliki asesoris atau perhiasan yang dipakai dalam tradisi budaya mereka mulai dari, berperang, perkawinan, dan alat tukar. Semua perhiasan ini terbuat atau memanfaatkan alam sekitar. 


\section{DAFTAR PUSTAKA}

Flassy, Don A. L. 2003. Refleksi Seni Rupa di Tanah Papua. Jakarta: Balai Pustaka.

Mansoben, Jhoszua Robert. 1995. Sistem Politik Tradisional di Irian Jaya. Jakarta: LIPI-RUL.

Poesponegoro, M. D. dan Nugroho Notosusanto. 1993. Sejarah Nasional Indonesia. Jakarta: Balai Pustaka.

Prasetyo, Bambang. 2004. Religi pada Masyarakat Prasejarah di Indonesia. Proyek Penelitian dan Pengembangan Arkeologi.

Redaksi. 2000. Metode Penelitian Arkeologi. Jakarta: Pusat Penelitian Arkeologi Nasional.

Soelaeman, M. Munandar. 2000. Ilmu Budaya Dasar. Bandung: Refika Aditama.

Soejono, R. P. dan R. Z. Leirissa. 2007. Sejarah Nasional Indonesia. Jakarta: Balai Pustaka. 